\title{
THE CARBOXYPEPTIDASE Y CATALYSED HYDROLYSIS OF INDOLEACRYLOYL IMIDAZOLE
}

\author{
by \\ BRIAN M. MARTIN', RONALD W. A. OLIVER ${ }^{2}$, JACK T. JOHANSEN \\ and THAMMAIAH VISWANATHA \\ Department of Chemistry. Carlsberg Laboratory, \\ Gamle Carlsberg Vej 10, DK-2500 Copenhagen Valby \\ IPresent address: Max-Planck Institute, Rheinlanddamm 201, \\ D-4600 Dortmund I, West Germany \\ 2Permanent address: University of Salford, Department of Chemistry, \\ Salford 5M5 4WT, England
}

Keywords: Carboxypeptidase Y, Acylenzyme intermediate. Thiol modification.

Reaction of carboxypeptidase $Y$ with the chromophoric substrate indoleacryloyl imidazole was found to proceed via an acylenzyme intermediate, indoleacryloyl-carboxypeptidase $Y$, which exhibited a blue shift in $\lambda_{\max }$ with increasing $\mathrm{pH} . \mathrm{Ag}^{+}$ions effectively prevented the acylation of the enzyme, while $\mathrm{Hg}^{++}$ions were found to retard the deacylation of the acyl enzyme intermediate. Cyanylation of the single thiol function in carboxypeptidase $\mathrm{Y}$ could be readily achieved in buffer media $(\mathrm{pH} 7.0$ ) containing $3.3 \mathrm{M}$ urea. Such modification had little effect on the activity of the enzyme towards its typical peptide and ester substrates, suggesting that the thiol group does not participate directly in the catalytic mechanism.

\footnotetext{
Abbreviations: ATEE, $\alpha, \mathrm{N}$-acetyl-L-tyrosine ethyl ester; Ag-CPDY, carboxypeptidase Y treated with 1.2 or 2.4 equivalents of silver ions; $\mathrm{Hg}$-CPDY, carboxypeptidase $\mathrm{Y}$ treated with 1.2 equivalents of mercuric ions; $\mathrm{CPDY}$, carboxypeptidase Y (E.C. 3·4·16·1); CT, chymotrypsin; DFP, diisopropyl fluorophosphate; IA, indoleacryloyl-: IAI, indoleacryloyl imidazole: NTCB, 2-nitro-5-thiocyanobenzoic-acid; PCMB, p-chloromercuribenzoic acid; Z. benzyloxycarbonyl.
} 


\section{INTRODUCTION}

The isolation of carboxypeptidase Y (CPDY) from autolysates of Saccharomyces cerevisiae and its characterization has been reported by several investigators $(1,21,29)$. More recently the isolation and purification of this enzyme was vastly simplified by the development of a novel affinity chromatography procedure in this laboratory (25). Carboxypeptidase $\mathrm{Y}$ is unique in view of the following: i) it is an exopeptidase without being a metallo protein (20); ii) it is inhibited by diisopropylfluorophosphate (DFP) (21) unlike other exopeptidases and has also been shown to contain an essential histidine residue (19) and hence has been classified as a serine protease; iii) it is a glycoprotein; the reported carbohydrate content varies from one laboratory to another, but at least four oligosaccharide chains are attached to asparagine residues in the main polypeptide chain $(17,18,39)$; and iv) it contains a single thiol function in the vicinity of active site $(3,21)$.

Although considerable information regarding the specificity of the enzyme is available (5), very little is known concerning the pathway of the reaction catalysed by it. Furthermore, modification of the thiol group of the enzyme has been achieved using either metal ions or mercurials (3, 4). The effect of the latter appears to be governed by the nature of substrate employed, with the amino acid residue at the $S_{1}$ subsite determining whether a given mercurial exerts inhibitory or potentiating influence on the enzyme (4).

Chromophoric acyl imidazoles have been successfully exploited in the elucidation of mechanism of the reactions catalysed by other serine proteases $(7,8,32,37)$. The advantage of incorporating such chromophores into typical substrates has been amply demonstrated $(6,15)$.

The purpose of the current investigation is to examine the reaction of carboxypeptidase $\mathrm{Y}$ with indoleacryloyl imidazole and to assess the effect of cyanylation of the thiol group on the catalytic function of the enzyme.

\section{EXPERIMENTAL}

\subsection{Materials}

Indoleacryloyl imidazole (IAI) was prepared by reaction of indoleacrylic acid with imidazole in the presence of dicyclohexyl carbodiimide (8).
The product was recrystallized from benzene. m.p. $191-192^{\circ} \mathrm{C} ; \lambda_{\max }=378 \mathrm{~nm}$ and $\varepsilon_{\max }=$ $2.32 \times 10^{4} 1 \cdot \mathrm{mol}^{-1} \cdot \mathrm{cm}^{-1}$.

2-Nitro-5-thiocyanobenzoic acid (NTCB) was prepared from 5,5'dithiobis (2-nitrobenzoic acid) according to the procedure of DEGANI and PATCHORNIK (12). m.p., $162^{\circ} \mathrm{C} ; \lambda_{\max } 293 \mathrm{~nm}$.

Carboxypeptidase Y (CPDY) was a laboratory preparation, isolated from autolysates of Saccharomyces cerevisiae by the affinity chromatography procedure (25).

\subsection{Reaction of CPDY with IAI:}

To one millilitre of enzyme $(15$ or $29 \mu \mathrm{M})$ in an appropriate buffer was added 2 or $5 \mu$ aliquot of a solution of $5 \mathrm{~mm} \mathrm{IAI}\left(\mathrm{CH}_{3} \mathrm{CN}\right.$ solvent), respectively. Following the recording of the absorption spectrum, the rate of deacylation was studied by monitoring the decrease in absorbance at $380 \mathrm{~nm}$. In all experiments, enzyme concentration was in slight excess over that of IAI.

In some experiments, solutions of enzyme at $\mathrm{pH} 7.75$ were pretreated with mercuric chloride or silver acetate and incubated for 30 minutes at $21^{\circ} \mathrm{C}$ prior to the initiation of reaction with IAI. The molar ratio of enzyme to $\mathrm{Hg}^{++}$ions was 1.0:1.2 while in the case of $\mathrm{Ag}^{+}$ions, this ratio was either $1.0: 1.2$ or $1.0: 2.4$.

The following buffers were employed: $\mathrm{pH}$ 4.50-5.50, $100 \mathrm{~mm}$-sodium acetate; $\mathrm{pH}$ 6.0-8.0, $100 \mathrm{~mm}$-potassium phosphate; $\mathrm{pH}$ above 8.0 , $100 \mathrm{~mm}$-sodium borate, containing $100-\mathrm{mm}$ $\mathrm{KCl}$. All experiments with IAI were performed at $25^{\circ} \mathrm{C}$.

\subsection{Modification of the thiol group of CPDY}

Quantitative estimation of SH-group in CPDY was achieved by titration of the enzyme ( $30 \mu \mathrm{M}$ in $50 \mathrm{~mm}$-potassium phosphate containing $6.0 \mathrm{M}$-urea, $\mathrm{pH} 7.0$ ) with $p$-chloromercuribenzoate (PCMB) according to the procedure described by BoYer (10).

Cyanylation of the thiol group of CPDY was accomplished as follows: CPDY $(30 \mu \mathrm{M})$ in 50 mM-potassium phosphate $(\mathrm{pH} 7.60)$ containing either 3.3 or $6.0 \mathrm{~m}$-urea, was treated with $5 \mu \mathrm{l}$ solution of NTCB (25 mм in 50 mm-potassium phosphate, $\mathrm{pH}$ 6.9). The reaction, which was monitored at $412 \mathrm{~nm}$, was terminated when no 
further increase in absorbance at this wavelength was noted. Contribution from the spontaneous hydrolysis of NTCB (obtained by incubating the reagent under identical conditions except for the omission of the enzyme) was subtracted from the increase in $A_{412 \mathrm{~nm}}$ noted above. Quantitative estimation of the thiol group in CPDY was based on $\triangle A_{412 \mathrm{~nm}}$ using an $\varepsilon_{\mathrm{M}}$ value of $1.36 \times 10^{4}$ $1 \cdot \mathrm{mol}^{-1} \mathrm{~cm}^{-1}$ for 2-nitro-5-thiobenzoate (12).

Large scale preparation of cyanylated CPDY was accomplished by reacting $1 \mathrm{ml}$ of a $0.2 \mathrm{~mm}$ solution of CPDY with $50 \mu \mathrm{l}$ of NTCB under conditions similar to those described above. The cyanylated enzyme was recovered from the reaction mixture by chromatography on a $2 \times 25$ $\mathrm{cm}$ column of Sephadex G-25 gel with water serving both as equilibrating medium and eluant.

\subsection{Measurement of activity}

Esterase activity was measured with ATEE (1 $\mathrm{mm}$ in $50 \mathrm{~mm}$-potassium phosphate, $\mathrm{pH} \mathrm{7.80)}$ as substrate by the spectrophotometric procedure of SchWERT and TAKENAKa (38).

Peptidase activity was determined by the spectrophotometric method (25) using Z-PheAla ( $2 \mathrm{~mm}$ in $20 \mathrm{~mm}$-MES buffer containing 1.0 mM-EDTA, pH 6.75) as substrate.

In these studies the concentration of CPDY was estimated using an $E_{280 \mathrm{~m}}^{1 \%}$ value of 14.8 and molecular weight of 64,000 for the protein (25). All spectrophotometric measurements were performed using a Cary Model 219 spectrophotometer.

\section{RESULTS}

\subsection{Reaction of CPDY with IAI}

\subsubsection{Active site titration}

Initial experiments concerned the stoichiometry of the reaction of CPDY with IAI. One millilitre of enzyme ( $30 \mu \mathrm{M}$ in $100 \mathrm{~mm}$-sodium acetate, $\mathrm{pH} 4.90$ ) was successively treated with four $2 \mu \mathrm{l}$ aliquots of IAI ( $5 \mathrm{~mm}$ in $\mathrm{CH}_{3} \mathrm{CN}$ ) and the absorbance at $400 \mathrm{~nm}$ was recorded after each addition of the reagent. The absorbance at $400 \mathrm{~nm}$ of the reaction mixture noted after such additions of IAI was subtracted from the value obtained for the same final concentration of the acyl imidazole under identical conditions except for the exclusion of the enzyme. Calculation of
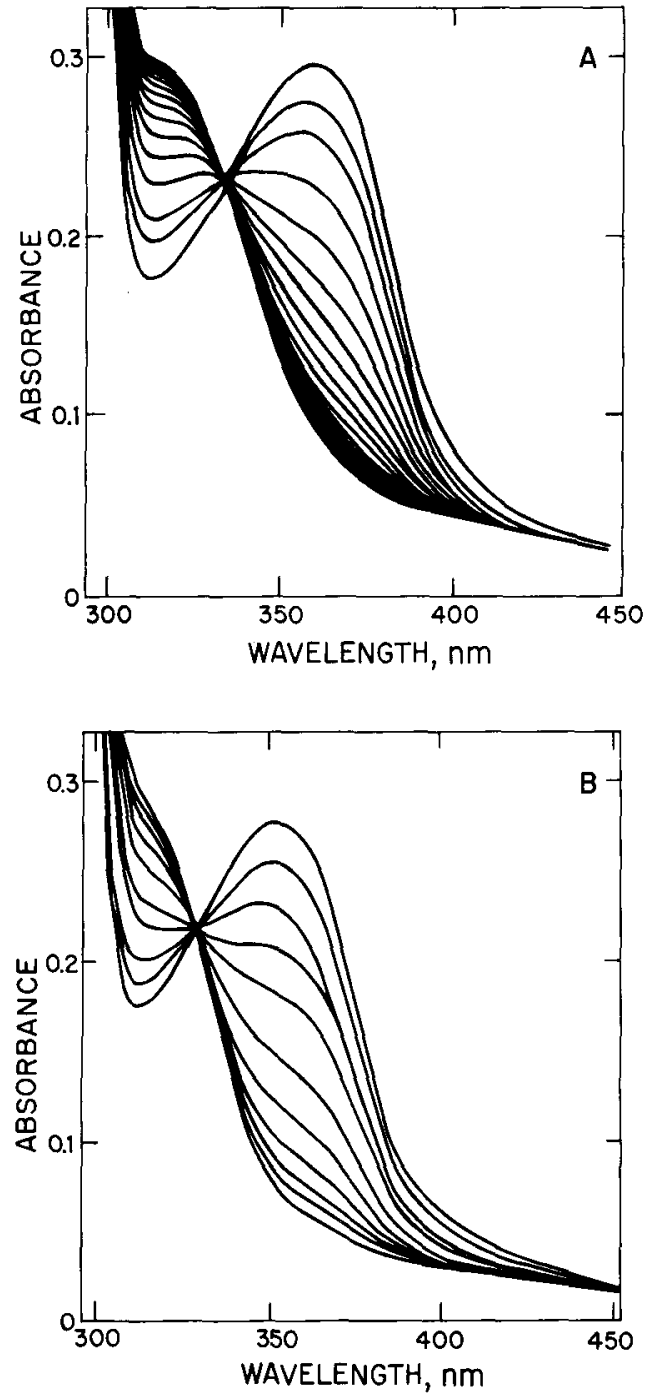

Figure 1. Absorption spectra of the carboxypeptidase $\mathrm{Y}$ reaction with $\mathrm{IAI}$ as a function of time.

One millilitre of $29 \mu \mathrm{M}-\mathrm{CPDY}$ in appropriate buffer was treated with five microlitres of $5 \mathrm{~mm}$-IAI. A. $100 \mathrm{~mm}$-sodium acetate, $\mathrm{pH} \mathrm{4.90.} \mathrm{The} \mathrm{first} \mathrm{three}$ spectra were recorded at $0,5.9$ and 11.8 minutes, respectively. All subsequent recordings were made at 12.3 minute intervals. B. $100 \mathrm{mM}$-Sodium borate, $\mathrm{pH}$ 9.06. Absorption spectra were recorded at the following times: $0,2,4,9.9,12.8,18.7,24.6,30.5$, $36.4,42.2$ and 51.9 minutes, respectively.

the operational molarity of the enzyme (37) from such $\triangle A_{400 \mathrm{~nm}}$ values revealed the presence of 1.02 active sites per mole of the protein. 


\subsubsection{Kinetics of reaction of CPDY with IAI}

The reaction of CPDY with IAI was examined over a $\mathrm{pH}$ range of 4.50 to 9.10 . At all $\mathrm{pH}$ values investigated, the reaction was accompanied by the rapid disappearance of IAI (as indicated by the absence of species with $\lambda_{\max }$ of $378 \mathrm{~nm}$ ) and the concomitant formation of an acylenzyme intermediate, followed by deacylation of the acylenzyme. At pH 4.90 (Figure 1A) the $\lambda_{\max }$ for the acylenzyme is $360 \mathrm{~nm}$, and during deacylation this band decreases, and a new band becomes progressively apparent at about $315 \mathrm{~nm}$, and an isosbestic point at $333 \mathrm{~nm}$ is observed. At pH 9.06 (Figure 1B) the $\lambda_{\max }$ for the acylenzyme intermediate is at $350 \mathrm{~nm}$ and the deacylation process is characterized by an isosbestic point at $329 \mathrm{~nm}$. Thus the $\lambda_{\max }$ for the acylenzyme intermediate is $\mathrm{pH}$ dependent and characterized by a blue shift with increasing $\mathrm{pH}$ (Table I). This shift in $\lambda_{\max }$ for the acylenzyme intermediate with $\mathrm{pH}$ was found to be reversible and governed by a group in the enzyme with a $\mathrm{pK}_{\mathrm{a}}^{\prime}$ of approximately 6.0. In contrast, the molar absorptivity $\left(2.0 \times 10^{4} 1 \cdot \mathrm{mol}^{-1} \cdot \mathrm{cm}^{-1}\right)$ at $\lambda_{\max }$ for the acylenzyme intermediate was not affected by the $\mathrm{pH}$ of the medium.

The deacylation process (Figure $1 \mathrm{~A}$ and $\mathrm{IB}$ ) obeyed first-order kinetics and was found to be $\mathrm{pH}$ dependent with maximum rates of deacylation at $\mathrm{pH}$ values 8.0 and above. A plot of the deacylation rate constants obtained at different $\mathrm{pH}$ values fits a titration curve with an apparent $\mathrm{pK}_{\mathrm{a}}^{\prime}$ of 6.0 (Figure 2). Thus both the rate of deacylation and the $\lambda_{\max }$ for the acylenzyme intermediate seem to depend on the same functional group in the enzyme exhibiting $\mathrm{pK}_{\mathrm{a}}^{\prime}$ of 6.0 .

\section{Table I}

$\lambda_{\max }$ of acyl-enzyme intermediate as a function of $\mathrm{pH}$.

\begin{tabular}{cc}
\hline $\mathrm{pH}$ & $\lambda_{\max }(\mathrm{nm})$ \\
\hline 4.90 & 360.0 \\
5.40 & 360.5 \\
5.96 & 354.0 \\
6.68 & 353.0 \\
7.28 & 351.5 \\
7.80 & 351.0 \\
9.00 & 352.0 \\
\hline
\end{tabular}

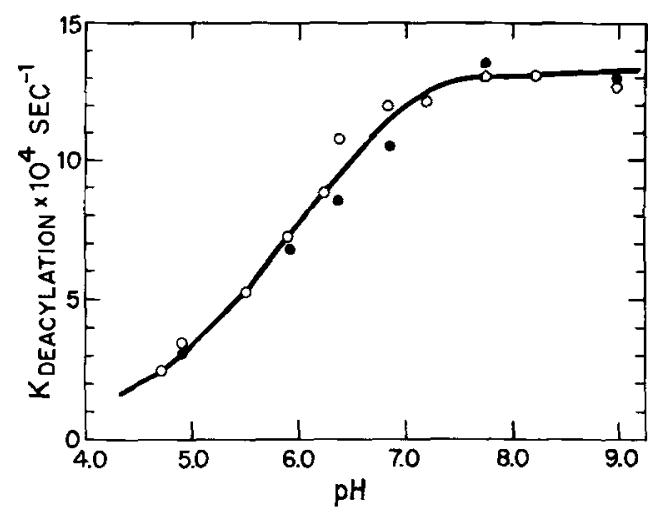

Figure 2. Effect of $\mathrm{pH}$ on the rate $\left(\mathrm{k}_{\mathrm{d}}\right)$ of deacylation of Indoleacryloyl-CPDY. o. CPDY; - cyanylated CPDY

\subsubsection{Reaction of IAI with Hg-CPDY}

CPDY was treated with a 1.2 fold molar excess of $\mathrm{HgCl}_{2}$ at $\mathrm{pH} 7.75$ and was subsequently tested for its activity towards typical ester and peptide substrates as well as towards IAI. Such Hg-CPDY preparations were found to have negligible activity towards ATEE $(<5 \%)$

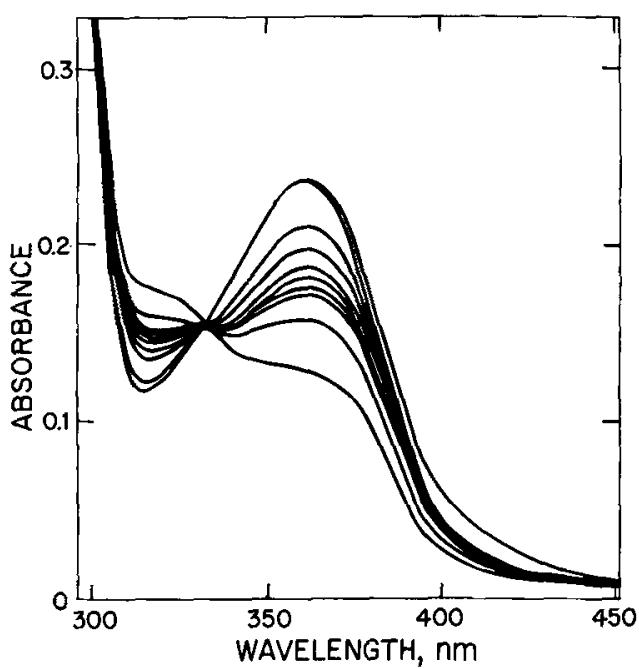

Figure 3. Absorption spectra of the $\mathrm{Hg}$-carboxypeptidase $\mathrm{Y}$ reaction with $\mathrm{IAI}$.

One millilitre of $29 \mu \mathrm{M}$ CPDY-potassium phosphate, $\mathrm{pH} 7.75$ was treated with twelve microlitres of $2.7 \mathrm{~mm}-\mathrm{HgCl}_{2}$ and allowed to stand at $25^{\circ} \mathrm{C}$ for 30 minutes. Four microlitres of $5 \mathrm{~mm}-1 \mathrm{Al}$ were added to the above mixture. Absorption spectra were recorded at the following times: $1,3,13,23,33,43,53,63$ and 153 minutes, respectively. 

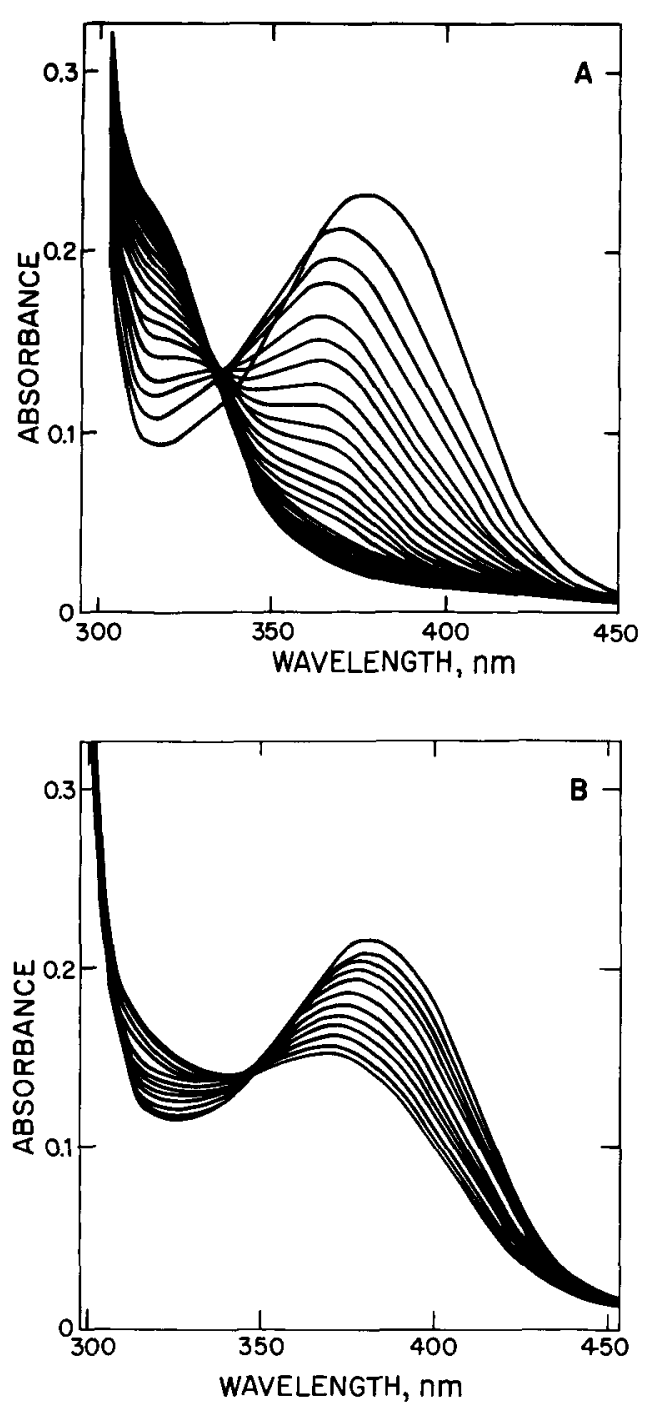

Figure 4. Absorption spectra of the Ag-carboxypeptidase $\mathrm{Y}$ reaction with $\mathrm{IAI}$.

A. One millilitre of $29 \mu \mathrm{M}-\mathrm{CPDY}$ in $50 \mathrm{~mm}$ potassium phosphate $\mathrm{pH}$ 7.75, was treated with twelve microlitres of $3 \mathrm{~mm}$-silver acetate and allowed to stand at $25^{\circ} \mathrm{C}$ for 2 hours. Four microlitres of 5 mm-IAI were added. The first six recordings of the absorption spectra were obtained at: $0,5,11,16,22$, and 27 minutes, respectively. All subsequent recordings were made at 5.5 minute intervals. B. Experimental conditions same as in A except that CPDY was preincubated with twentyfive microlitres of $3 \mathrm{~mm}$-silver acetate. Absorption spectra recorded at the following time intervals: $0,4.1,8.2,12.4$, $16.5,22.7,29.0,35.1,42.2,45.1,49.4$ and 53.7 minutes, respectively. but still exhibited considerable (approximately $30 \%$ relative to the unmodified enzyme) acitivity towards Z-Phe-Ala. The reaction of $\mathrm{Hg}$-CPDY with IAI at $\mathrm{pH} 7.75$ is shown in Figure 3. Treatment of the enzyme with $\mathrm{Hg}^{++}$ions had no apparent effect under the conditions of the experiment on the acylation step, the formation of the acylenzyme intermediate being observed immediately after the addition of the chromophoric substrate. These ions, however, appeared to inhibit the deacylation process.

An interesting feature of the acylenzyme intermediate formed in the presence of $\mathrm{Hg}^{++}$ ions is the absence of a blue shift normally associated with it at high $\mathrm{pH}$. The $\lambda_{\max }(362 \mathrm{~nm})$ of the acylenzyme intermediate obtained with $\mathrm{Hg}$-CPDY at $\mathrm{pH} 7.75$ is identical (within experimental error) with that of the acylenzyme obtained with untreated enzyme at pH 4.90.

\subsubsection{Reaction of IAI with Ag-CPDY}

The effect of $\mathrm{Ag}^{+}$ions on the reaction of IAI with CPDY is illustrated in figures $4 \mathrm{~A}$ and $4 \mathrm{~B}$. At a molar ratio of enzyme to $\mathrm{Ag}^{+}$ions of 1:1.2, acylation of the enzyme was considerably impaired, but the inhibition was incomplete (Fig $4 \mathrm{~A}$ ). Besides the normal decay due to spontaneous process, the presence of free enzyme (not complexed with $\mathrm{Ag}^{+}$ions) in the reaction mixture appears to have contributed to the hydrolysis of IAI. In contrast, at higher $\mathrm{Ag}^{+}$ion concentrations (molar ratio of enzyme to $\mathrm{Ag}^{+}$ ions of $1: 2.40$ ) complete inhibition of acylation was observed (Fig 4B). The presence of intact IAI was evident even after sixty minutes of the initiation of the reaction. The hydrolysis of IAI observed under these conditions appears to be primarily due to the spontaneous process mediated by the $\mathrm{OH}^{-}$ions present in the medium, as revealed by control experiments.

\subsubsection{Reaction of CPDY with NTCB}

Titration of CPDY with PCMB according to the procedure of BOYER (10) revealed the presence of one mole of thiol group per mole of enzyme. In contrast the thiol group in the native enzyme was inaccessible to modification by NTCB. No increase in absorbance at $412 \mathrm{~nm}$ 
could be observed even after prolonged incubation of the native enzyme with NTCB. However, the reaction was facilitated by inclusion of $6 \mathrm{M}$ urea in the reaction medium. The release of 2 nitro-5-thio benzoate (as reflected in the increase in absorbance at $412 \mathrm{~nm}$ ) was virtually complete 60 minutes after the initiation of the reaction. The amount of 2-nitro-5-thio benzoate released corresponded to 0.94 moles per mole of enzyme, confirming the presence of a single thiol function in the enzyme. The cyanylated enzyme preparation (following recovery from the reaction mixture) was devoided of activity towards ATEE and Z-Phe-Ala. Control experiments with protein alone in $50 \mathrm{~mm}$-potassium phosphate buffer containing urea $(6.0 \mathrm{~m}), \mathrm{pH} 7.40$, revealed a rapid loss of activity towards typical substrates, presumably due to denaturation of the enzyme.

To assess the effect of cyanylation of the thiol function, efforts were made to find the minimum concentration of urea that would facilitate $-\mathrm{SH}$ modification without causing irreversible denaturation of the protein. It was found that the enzyme was stable in $50 \mathrm{~mm}$-potassium phosphate buffer containing 3.3 м-urea, $\mathrm{pH} \mathrm{7.60.}$ Under these conditions enzyme activity towards typical substrates remained intact over a period of 4-5 hours and also permitted cyanylation of the thiol group. Approximately $50 \%$ of the thiol group of the enzyme was modified after three hours of initiation of the reaction with NTCB. Examination of modified protein at this stage revealed that cyanylation of the thiol function had very little influence on the activity of the enzyme towards typical substrates.

The cyanylated enzyme was found to undergo facile acylation with IAI and the kinetics of deacylation of the resultant acylenzyme intermediate were similar to that observed in experiments with unmodified enzyme (Figure 2).

\section{DISCUSSION}

The reaction of IAI with CPDY occurs via the acylenzyme pathway: CPDY $+\mathrm{IAI} \leftrightarrows$ $(\mathrm{CPDY} \cdot \mathrm{IAI}) \rightarrow \mathrm{IA}-\mathrm{CPDY} \rightarrow \mathrm{IA}+\mathrm{CPDY}$

The $\lambda_{\max }$ of the acylenzyme intermediate is dependent on the $\mathrm{pH}$ of the medium, with a shift towards lower wavelength occurring with increasing $\mathrm{pH}$ values. At all $\mathrm{pH}$ values investigated the $\lambda_{\max }$ of the acylenzyme intermediate clearly demonstrates the presence of the acyl moiety on a functional group similar to that observed with other serine proteases. The possibility of formation of a thiol ester intermediate characterized by a $\lambda_{\max } 398 \mathrm{~nm}(22)$ is thus virtually eliminated and consequently the single thiol function of CPDY does not appear to participate in the reaction with IAI.

The $\mathrm{pH}$ dependent shift in the $\lambda_{\max }$ of the acylenzyme intermediate is analogous to that observed with indoleacryloyl-chymotrypsin (8). Factors contributing to such shifts in $\lambda_{\max }$ of the acylenzyme intermediate remain to be established. The $\mathrm{pH}$ dependence of deacylation of the acylenzyme intermediate exhibits a sigmoidal profile with half-maximal deacylation being achieved at $\mathrm{pH}$ 6.0. This $\mathrm{pK}_{\mathrm{a}}^{\prime}$ value for the group involved in the deacylation process is identical with that found in the reversible transition of the acylenzyme intermediate between species with $\lambda_{\max }$ of $360 \mathrm{~nm}$ and $350 \mathrm{~nm}$. The $\mathrm{pK}_{\mathrm{a}}^{\prime}$ value (7.68) for the group involved in the deacylation of IA-chymotrypsin has been reported to be approximately $0.5 \mathrm{pH}$ units higher than the value $\left(\mathrm{pK}_{\mathrm{a}}^{\prime}=7.15\right)$ normally observed with other acyl derivatives of the enzyme (8). If similar considerations were to apply to CPDY, the $\mathrm{pK}_{\mathrm{a}}^{\prime}$ value of the group involved in the deacylation step with normal substrates and other chromophoric acyl imidazoles should be expected to be approximately 5.50 , a value in good agreement with that reported earlier with typical substrates (5).

$\mathrm{Ag}^{+}$and $\mathrm{Hg}^{++}$ions exerted different effects on CPDY catalysed hydrolysis of IAI. The former exerted profound inhibition on the reaction, with IAI being still present in the reaction mixture 60 minutes after the initiation of the reaction while it is normally consumed within seconds. The hydrolysis of IAI noted in the presence of Ag-CPDY was restricted to a $\mathrm{OH}^{-}$mediated, spontaneous hydrolysis of the reagent. $\mathrm{Ag}^{+}$ions appear to block the initial step, namely, acylation of the enzyme by IAI. These observations are consistent with the report on the selective interaction of $\mathrm{Ag}^{+}$ions at the Asp $_{102}$-His 57 segment of the »catalytic triad « of trypsin resulting in the inhibition of acylation of the enzyme (11). The current observations on the inhibition of acylation of CPDY by $\mathrm{Ag}^{+}$ions constitute the first evidence for the possible 
involvement of a carboxyl group in the catalytic function of the enzyme. Thus, carboxypeptidase $Y$ appears to have similar geometric arrangements of functional groups in the active site as observed for other serine proteases (28).

$\mathrm{Hg}^{++}$ions, in contrast to the above observations, had no observable effect on the acylation of the enzyme by IAI. The $\lambda_{\max }(362 \mathrm{~nm})$ of the acylenzyme intermediate obtained at $\mathrm{pH} 7.75$ was identical with that normally observed at acidic $\mathrm{pH}$ values. Thus, $\mathrm{Hg}^{++}$ions appear to "freeze" the $\mathrm{pH}$ dependent blue shift in the $\lambda_{\max }$ of the acyl enzyme. Such a stabilization of the acyl enzyme intermediate of $\lambda_{\max } 360 \mathrm{~nm}$ is accompanied by a marked diminution of the rate of deacylation. The site of interaction of $\mathrm{Hg}^{++}$ ions thus appears to be distinct from that of $\mathrm{Ag}^{+}$ ions. $\mathrm{Hg}^{++}$ions can be expected to interact with the single thiol group of the enzyme. Modification of this sulfhydryl per se should have little effect on either the acylation of the enzyme by IAI or on subsequent deacylation of the acylenzyme intermediate, since selective cyanylation of this thiol function has no adverse affect on the catalytic function (see discussion below). The fact that $\mathrm{Hg}^{++}$ions do inhibit the deacylation process would indicate a more complex interaction of these ions with the protein than just the selective modification of the thiol group. It is not clear at the present whether $\mathrm{Hg}^{++}$ions facilitate a conformational change due to dimerization of the protein by forming a mercaptide bridge between the enzyme molecules or an intramolecular interaction involving the thiol and another appropriate functional group in the protein. The effect of $\mathrm{Hg}^{++}$ions thus appears to be indirect with the modification of the thiol group located in the vicinity of the sactive site of the protein being responsible for the lowered rate of deacylation. Indeed, the divergent effects, inhibition or activation, of different mercurials have been attributed to the modification of the thiol function at the enzyme subsite corresponding to the penultimate residue of the substrate (4). These reagents, however, may be nonspecific in their interaction and hence unable to provide unequivocal information concerning the role of the thiol in the catalytic function of the enzyme.

Selectivity of the reaction of NTCB towards thiol groups in proteins has been documented (13) and this reagent has been used not only to establish the absolute requirement for such a functional group in the catalytic function of the protein (13) but also to effect selective cleavage of proteins at the cysteine residues $(14,24)$. The failure of NTCB to effect modification of native CPDY suggests that the thiol function is buried in the interior of the protein molecule. Facile modification of the thiol of CPDY could be accomplished in medium containing $6.0 \mathrm{M}$-urea due to unfolding of the protein. In contrast to the above observations, enzyme activity towards typical substrates was found to be preserved over a period of several hours in a medium of $3.3 \mathrm{M}$ urea, a condition which also permitted cyanylation of the thiol function by NTCB. The presence of full enzymatic activity in cyanylated CPDY preparations towards typical substrates as well as IAI provides unambigous evidence for the noninvolvement of the thiol function in the catalytic mechanism of the enzyme.

The observations recorded in this study confirm the classification of CPDY as a serine protease. The overall reaction mechanism appears to involve an acylenzyme intermediate, as has been observed with other members of this family of enzymes. Based on the primary structure as well as X-ray diffraction data of chymotrypsin, a novel concept of a »charge relay system « comprising Asp 102 , His 57 and Ser 195 was formulated to provide the chemical basis for the catalytic activity of this protein (9). The presence of such a catalytic triad in other serine proteases has been generally accepted.

Criticisms $(23,33)$ of the above mentioned proposal of the »charge relay system «, mainly concerning the adverse effects of the unfavourable charge separation accompanying the formation of the tetrahedral intermediate in the acylation step, appeared to have been overcome by the reasignment of $\mathrm{pK}_{\mathrm{a}}^{\prime}$ values for the functional groups in the catalytic triad (23). Thus, in the studies with $\alpha$-lytic protease, a serine protease of bacterial origin, the aspartic acid residue was shown to behave like a weak acid with $\mathrm{pK}_{\mathrm{a}}$ value of 6.70 while the histidine residue served as a weak base with $\mathrm{pK}_{\mathrm{a}}^{\prime}$ value well below 4.0 (23). Confirmatory evidence for the high $\mathrm{pK}_{\mathrm{a}}^{\prime}$ value of the aspartic acid residue has also been obtained by far infrared investigations of trypsin (27). More recent investigations, however, have failed to provide support for the 
Table II

Assignment of the $\mathrm{pK}^{\prime}$ a values to functional groups in the proton relay system of serine proteases

\begin{tabular}{|c|c|c|c|c|}
\hline Enzyme & $\mathrm{pK}_{\mathrm{a}}^{\prime}$ & Assignment & Technique & Ref. No. \\
\hline$\alpha$-lytic protease & $\begin{array}{l}6.7 \\
4.0\end{array}$ & $\begin{array}{l}\text { Asp } \\
\text { His }\end{array}$ & $\begin{array}{c}13 \mathrm{C} \\
\text { N.M.R. }\end{array}$ & (23) \\
\hline $\begin{array}{l}\text { trypsin } \\
\text { chymotrypsin } \\
\text { subtilisin } \\
\alpha \text {-lytic protease }\end{array}$ & 7.5 & $\begin{array}{l}\text { NH proton } \\
\text { His ----Asp }\end{array}$ & $\begin{array}{l}{ }^{\mathrm{l}} \mathrm{H} \\
\text { low field } \\
\text { N.M.R. }\end{array}$ & $(35,36)$ \\
\hline porcine trypsin & 4.5 & His & $\begin{array}{c}\text { IH } \\
\text { N.M.R. }\end{array}$ & $(30,31)$ \\
\hline trypsin & 6.8 & Asp & I.R. & (27) \\
\hline$\alpha$-lytic protease & 7 & $\begin{array}{l}\mathrm{His} \\
\mathrm{N}(3)\end{array}$ & $15_{N}$ & (2) \\
\hline $\begin{array}{l}\alpha \text {-lytic protease } \\
\text { chymotrypsin } \\
\text { porcine trypsin }\end{array}$ & $\begin{array}{l}5.7 \\
6.8 \\
5.0\end{array}$ & $\begin{array}{l}\text { His } \\
\text { His } \\
\text { His }\end{array}$ & $\begin{array}{c}{ }^{l} \mathrm{H} \\
\text { N.M.R. }\end{array}$ & (34) \\
\hline
\end{tabular}

postulated $\mathrm{pK}_{\mathrm{a}}^{\prime}$ values of the functional groups, comprising the »charge relay system $\ll$. The $\mathrm{pK}_{\mathrm{a}}$ values of histidine and aspartic acid residues in the catalytic triad of various serine proteases, documented in literature thus far are summarized in Table II. An examination of the data reveals a complete absence of concensus in the $\mathrm{pK}_{\mathrm{a}}^{\prime}$ values assigned to the functional groups. The problems associated with the wcharge relay system « have been elegantly discussed by $\mathrm{BA}_{\mathrm{A} \text { - }}$ CHOVCHIN and ROBERTS (2) who, on the basis of NMR studies on $\alpha$-lytic protease with a ${ }^{15} \mathrm{~N}$ enriched histidine residue, have been able to demonstrate the inability of the currently accepted proposals to provide the basis for catalytic mechanism of serine proteases. Furthermore, reexamination of $\mathrm{X}$-ray diffraction data have revealed that the serine residue is far removed from the aspartic acid and histidine residues and hence unlikely to provide the $»$ proton relay system" as earlier postulated (28). As an alternative to the "proton relay system«, propo- sals involving the participation of imidazole and the imidazolium nucleus of histidine 57 and with water serving as the ultimate proton sink have been advanced (26). It is evident from the aforementioned observations that the structural basis of catalysis in serine proteases is far from being elucidated.

CPDY, despite its similarity to other serine proteases with respect to the nature and the geometry of the functional groups comprising the active site, is endowed with several features that distinguishes it from other members of the family. Besides those already recorded in the introduction, the low $\mathrm{pK}_{\mathrm{a}}^{\prime}$ value, relative to that observed in other serine proteases, of the functional group governing the deacylation of the acylenzyme intermediate, is indeed noteworthy. Elucidation of the acid-base properties of the functional groups in the active site of this enzyme could lead to the clarification of the mechanism of action of serine proteases. 


\section{ACKNOWLEDGEMENT}

The authors wish to express their appreciation to professor MARTIN OTTESEN for helpful discussions during the course of this work.

\section{REFERENCES}

1. Aibara, S., R. Hayashi \& T. Hata: Physical and Chemical Properties of Yeast Proteinase C: Agr. Biol. Chem. 35, 658-66 (1971)

2. Bachovchin, W. W. \& J. D. Roberts: Nitrogen-15 Nuclear Magnetic Resonance Spectroscopy. The State of Histidine in the Catalytic Triad of $\alpha$-Lytic Protease. Implications for the Charge-Relay Mechanicm of Peptide-Bond Cleavage by Serine Proteases. J. Am. Chem. Soc. 100, 8041-8047 (1978)

3. BaI, Y. \& R. Hayashi: A Possible Role for a Single Cysteine Residue in Carboxypeptidase $Y$ : FEBS Letters 56, 43-45 (1975)

4. Bai, Y. \& R. Hayashi: Properties of the Single Sulfhydryl Group of Carboxypeptidase Y: J. Biol. Chem. 254, 8473-79 (1979)

5. BaI, Y., R. Hayashi \& T. Hata: Kinetic Studies of Carboxypeptidase Y: III. Action on Ester, Amide and Anilide Substrates and the Effects of Some Environmental Factors: J. Biochem. 78, 617-26 (1975)

6. Barman, T. E. \& H. Gutfreund: Optical and Chemical Identification of Kinetic Steps in Trypsin- and Chymotrypsin-Catalysed Reactions. Biochem. J. 101, 411-16 (1966)

7. Bernhard, S. A., S. J. Lau \& H. Noller: Spectrophotometric Identification of Acyl Enzyme Intermediates. Biochemistry 4, 1108-18 (1965)

8. Bernhard, S. A. \& Z. H. Tashitan: Acyl Intermediates in the $\alpha$-Chymotrypsin Catalyzed Hydrolysis of Indoleacryloylimidazole. J. Am. Chem. Soc. 87, 1806-07 (1965)

9. Blow, D. M.. J. J. Birktøft \& B. S. Hartley: Role of a Buried Acid Group in the Mechanism of Action of Chymotrypsin. Nature 221, 337-40 (1969)

10. BOYER, P. D.: Spectrophotometric Study of Reaction of Protein Sulfhydryl Groups with Organic Mercurials. J. Am. Chem. Soc. 76, 4331-37 (1954)

11. Chambers, J.-L., G. G. Christoph, M. Krieger, L. KAY \& R. M. STROUd: Silver Ion Inhibition of Serine Proteases: Crystallographic Study of Silver-Trypsin. Biochem. Biophys. Res. Comm. $59,70-74$ (1974)
12. Degani, Y. \& A. Patchornik: Selective Cyanylation of Sulfhydryl Groups: On the Synthesis of 2-nitro-5-thiocyanato Benzoic acid. J. Org. Chem. 36, 2727-28 (1971)

13. Degani, Y. and A. Patchornik: Cyanylation of Sulfhydryl Groups by 2-Nitro-5-Thiocyanobenzoic Acid. High-Yield Modification and Cleavage of Peptides of Cysteine Residues. Biochemistry 13, 1-11 (1974)

14. Der Terrossian, E. \& R. Kassab: Preparation and Properties of S-Cyano Derivatives of Creatine Kinase. Eur. J. Biochem. 70, 623-28 (1976)

15. FINK, A. L.: Cryoenzymology: The Study of Enzyme Mechanisms at Subzero Temperatures. Accounts Chem. Res. 10, 233-38 (1977)

16. Friedman, M., L. H. Kruli. \& J. F. Cavins: The Chromatographic determinations of Cystine and Cysteine Residues in Proteins as S- $\beta$-(4-pyridylethyl) Cysteine. J. Biol. Chem. 245, 3868-71 (1970)

17. Hasilik, A. \& W. Tanner: Inhibition of the Apparent Rate of Synthesis of the Vacuolar Glycoprotein Carboxypeptidase $Y$ and its Protein Antigen by Tunicamycin in Saccharomyces Cerevisiae. Antimicrobiol. Agents and Chemetherapy 10, 402-10 (1976)

18. Hasilik, A. \& W. TANner: Carbohydrate Moiety of Carboxypeptidase $Y$ and Peturbation of its Biosynthesis. Eur. J. Biochem. 91, 567-75 (1978)

19. Hayashi, R., Y. Bai \& T. Hata: Evidence for an Essential Histidine in Carboxypeptidase $\mathrm{Y}$. J. Biol. Chem. 250, 5221-26 (1975)

20. Hayashi, R., Y. BaI \& T. HaTA: Further Confirmation of Carboxypeptidase $Y$ as a Metalfree Enzyme having a Reactive Serine Residue. J. Biochem. 77, 1313-18 (1975)

21. Hayashi, R., S. Moore \& W. H. Stein: Carboxypeptidase from Yeast. Large Scale Preparation and the Application to $\mathrm{COOH}$-terminal Analysis of Peptides and Proteins. J. Biol. Chem. 248, 2296-2302 (1973)

22. Hinkle, P. M. \& J. F. KirsCh: Evidence for Conformational Restrictions within the Active Site of Acyl Papains which Influence the Rates of Hydrolysis. Biochemistry 9, 4633-44 (1970)

23. Hunkapiller, M. W., S. H. Smallcombe, D. R. WhitAKeR \& J. H. RichaRds: Carbon Nuclear Magnetic Resonance Studies of the Histidine Residue in $\alpha$-Lytic Protease. Implications for the Catalytic Mechanism of Serine Proteases. Biochemistry 12. 4732-43 (1973)

24. Jacobsei, G. R., M. H. Schaffer. G. R. SiakK \& J. C. Vavaman: Specific Chemical Cleavage in High Yield at the Amino Peptide Bonds of 
Cysteine and Cystine Residues. J. Biol. Chem. 248, 6583-9! (1973)

25. Johansen, J. T., K. Breddam \& M. Ottesen: Isolation of Carboxypeptidase $\mathrm{Y}$ by Affinity Chromatography. Carlsberg Res. Comm. 41. 115 (1976)

26. Johnson, P. E., J. A. Stewart \& K. G. D. ALlen: Specificity of $\alpha$-chymotrypsin with Exposed Carboxyl Groups Blocked. J. Biol. Chem 251, 2353-62 (1976)

27. Koeppe, R. E. II \& R. M. Stroud: Mechanism of Hydrolysis by Serine Proteases: Direct Determination of the $\mathrm{pK}_{\mathrm{a}}$ 's of Aspartyl-102 and Aspartyl-194 in Bovine Trypsin Using Difference Infrared Spectroscopy. Biochemistry 15, 345058 (1976)

28. Kraut, J.: Serine Proteases: Structure and Mechanism of Catalysis. Ann. Rev. Biochem. 46, 331-358 (1977)

29. Kuhn, R. W., K. A. Walsh \& H. Neurath: Isolation and Partial Characterization of an Acid Carboxypeptidase from Yeast. Biochemistry 13, 3871-77 (1974)

30. MarkLEY, J. L.: Observation of Histidine Residues in Proteins by Means of Nuclear Magnetic Resonance Spectroscopy. Acc. Chem. Res. 8. 70-80 (1975)

31. Markiey, J. L. \& M. A. Porubcan: The Charge Relay System of Serine Proteinases: Proton Magnetic Resonance Titration Studies of the Four Histidines of Porcine Trypsin. J. Mol. Biol. 102, 487-509 (1976)

32. Oliver, R. W. A., T. Vismanatha \& W. J. D. WhisH: Acyl Derivatives of a-chymotrypsin.
Biochem. Biophys. Res. Comm. 27, 107-111 (1967)

33. Polgar, L. \& M. Bender: The Nature of General Base General Acid Catalysis in Serine Proteases. Proc. Nat. Acad. Sci. 64, 1335-42 (1969)

34. Perubcan, M. A., W. M. Weatler, I. B. lbanez \& J. L. MarkLeY: (Diisopropylphosphoryl) serine Proteinases. Proton and Phosphorus 31 Nuclear Magnetic Resonance pH Titration Studies. Biochemistry 18, 4108-16 (1979)

35. Robillard, G. \& R. G. Shulman: High Resolution Nuclear Magnetic Resonance Studies of the Active Site of Chymotrypsin I. The Hydrogen Bonded Protons of the "Charge Relay « System. J. Mol. Biol. 86, 519-540 (1974)

36. Robil. iard, G. \& R. G. Shulman: High Resolution Nuclear Magnetic Resonance Studies of the Active Site of Chymotrypsin II. Polarization of Histidine-57 by Substrate Analogues. J. Mol. Biol. 86, 541-558 (1974)

37. Schonbaum, G. R., B. Zerner \& M. L. Bender: The Spectrophotometric Determination of the Operational Normality of an $\alpha$-chymotrypsin Solution. J. Biol. Chem. 236, 2930-35 (1961)

38. Schwert, G. W. \& Y. Takenaka: A Spectrophotometric Determination of Trypsin and Chy. motrypsin. Biochim. Biophys. Acta. 16, 570-75 (1955)

39. Trimbie, R. B. \& F. Mal.ey: The Use of Endo- $\beta-$ $\mathrm{N}$-acetyl-glucosaminidase $\mathrm{H}$ in Characterizing the Structure and Function of Glycoproteins. Biochem. Biophys. Res. Comm. 78, 935-944 (1977) 